University of Windsor

Scholarship at UWindsor

1995

\title{
Lack of racial differences in behavior: A quantitative replication of Rushton's (1988) review and an independent meta-analysis
}

Kevin M. Gorey

University of Windsor

Arthur G. Cryns

University at Buffalo

Follow this and additional works at: https://scholar.uwindsor.ca/socialworkpub

Part of the Personality and Social Contexts Commons, and the Social Work Commons

\section{Recommended Citation}

Gorey, Kevin M. and Cryns, Arthur G.. (1995). Lack of racial differences in behavior: A quantitative replication of Rushton's (1988) review and an independent meta-analysis. Personality and Individual Differences, 19 (3), 345-353.

https://scholar.uwindsor.ca/socialworkpub/14

This Article is brought to you for free and open access by the School of Social Work at Scholarship at UWindsor. It has been accepted for inclusion in Social Work Publications by an authorized administrator of Scholarship at UWindsor. For more information, please contact scholarship@uwindsor.ca. 


\title{
LACK OF RACIAL DIFFERENCES IN BEHAVIOR: A QUANTITATIVE REPLICATION OF RUSHTON'S (1988) REVIEW AND AN INDEPENDENT META-ANALYSIS
}

\author{
Kevin M. Gorey ${ }^{1 . *}$ and Arthur G. Cryns ${ }^{2}$ \\ 'School of Social Work, University of Windsor, 401 Sunset Avenue, Windsor, Ontario, Canada N9B \\ 3P4 and ${ }^{2}$ School of Social Work, State University of New York at Buffalo, 359 Baldy Hall, P.O. Box \\ 601050, Buffalo, NY 14260-1050, U.S.A.
}

(Received 27 October 1994)

\begin{abstract}
Summary - Rushton (Personality and Individual Differences, 9, 1009-1024, 1988) hypothesized that racial group differences exist across a range of behaviors from intelligence to social organization. Such differences were then discussed within the context of an evolutionary continuum (Negroid $<$ Caucasoid $<$ Mongoloid). For example, his observations that blacks compared to whites are less intelligent, physically mature more rapidly, and are more aggressive and impulsive (less law abiding) were said to support the evolutionary hypothesis. Quantitative replication of the 100 studies included in Rushton's original 'review and evolutionary analysis' and a meta-analysis of 100 randomly selected studies infer that any behavioral differences which do exist between blacks, whites and Asian Americans for example, can be explained in toto by environmental differences which exist between them.
\end{abstract}

\section{INTRODUCTION}

Six years ago Rushton (1988) hypothesized that racial group differences exist on brain size and intelligence (e.g. brain weight and test scores), maturation rate (gestation time and skeletal development), personality and temperament (aggressiveness and impulsivity), sexuality (size of genitalia and permissive attitudes) and social organization (marital stability and mental health). The between-group differences which he observed were then discussed in an evolutionary context, specifically, differential $K$ theory-along the $r / K$ continuum of reproductive strategies (e.g. from sing'e cell animals to humans), $K$-selection essentially maximizes parental care and minimizes birthrate. Rushton further suggested that the races can be described along a continuum from relatively less to greater $K$-selection, that is, Negroid < Caucasoid < Mongoloid. His observations that Negroids compared to Caucasoids for example, are less intelligent, physically mature more rapidly, are more aggressive and impulsive (less law abiding) and less mentally healthy were said to support the evolutionary hypothesis.

Needless to say, Rushton's contentions caused quite a stir in the professional press. A search of the Psychological Abstracts data base on the key word Rushton (1988-1994) for example, found 34 papers which included some element of debate between Rushton and others: all of them cite Rushton's (1988) 'review and evolutionary analysis' paper (see ReferencesSpecial Section A). This expansive (135 reference citations covering approx. 50 years of research in this field) qualitative review, which has been a cornerstone in Rushton's theorizing, has been criticized on a number of methodologic and theoretical grounds. The central arguments though have concerned bias in selection of primary studies for inclusion in the review as well as the inadequacy of its accounting for environment-related alternative explanations, specifically, socioeconomic ones (Cunningham \& Barbee, 1991; Lynn, 1989a, b; Zuckerman \& Brody, 1988). This study will provide an interpretive adjunct to Rushton's (1988) original analysis by means of a quantitative replication of it.

\footnotetext{
*To whom all correspondence should be addressed
} 


\section{METHOD}

\section{Rushton's (1988) sample of studies}

Rushton cited 100 references in the five subsections or behavioral domains (brain size and intelligence, maturation rate, personality and temperament, sexual restraint, and social organization) of the 'Results' section of his original review (1988): 67 independent studies and 33 reviews. A scale-free metric-the $r$-index-which is interpretable as Pearson's linear correlation coefficient and estimates the strength of the race-behavior association, was calculated for each independent study which provided sufficient data (Cooper, 1989; Glass, McGaw \& Smith, 1981): 36 (53.7\%) reported data which allowed for such effect size estimation (see References-Special Section B). Pearson's $r$ is calculable from a variety of outcome statistics ( $t$-test, $F$-ratio, $\chi^{2}, P$-level with $n$ s, and group $M$ s with SDs), and thus allows for ease of across-study comparison and summary.

Analysis. Effect sizes were averaged (mean) across operational measures within behavioral domains, for example, three measures of intelligence reported in an original study would be averaged to produce one review outcome. However, if a study reported findings for two separate behavioral domains or if it made two different racial comparisons (e.g. Caucasoid-Negroid and Ca-Mongoloid), both outcomes were included in this review: 40 outcomes arose from the 36 studies. Next, $r$-indexes were averaged within each behavioral domain and racial comparison and the significance of each was estimated by the method of combining unweighted probabilities (Rosenthal, 1978; Stouffer, Suchman $\&$ DeVinney, 1949). Among the 36 studies included in this analysis, sample size $(n)$ was not found to be associated with effect size, so the across-study combined probability was not weighted by individual study' sample size.

\section{Random sample of studies}

Because the validity of Rushton's procedures for study selection has been questioned, a random sample of studies was included in this quantitative review. From a meta-analytic perspective, they may be thought of as the comparison group. Computer searches were conducted of available data bases (1965-1994_Dialog, Educational Resources Information Catalogue (ERIC), Medline, Psychological and Sociological Abstracts) using the same broad conceptual subject key word scheme as Rushton (1988, see Table 1): 1614 manuscripts were retrieved from which a sample of 100 were randomly selected -80 independent studies and 20 reviews. Of the independent studies, $65(81.3 \%)$ reported data which was sufficient for effect size estimation (see References-Special Section C). These 65 studies produced 73 outcomes which were analyzed in the same manner as Rushton's sample of studies.

One further methodological caveat ought to be discussed briefly. These authors will use the racial group terminology of black, white and Asian as synonyms for Rushton's preferred terms of Negroid, Caucasoid and Mongoloid, respectively. This usage is consistent with nearly all of the studies in this field, except those published by Rushton.

\section{RESULTS}

\section{Sample description}

The vast majority $(88.1 \%)$ of this review's primary studies used U.S. Ss only and the Rushton and random samples do not differ on this score. The Rushton sample (1976.9) does however, pre-date the random one (1984.2) by nearly a decade on average publication date; $F(1,99)=23.80, P<0.001$. Also, nearly all of the research designs $(>90.0 \%)$ among both of the samples of studies may be categorized as correlational or cross-sectional prevalence surveys. This is not surprising given the non-manipulative nature of the hypothesized independent variable, that is, race. Perhaps most important for the ultimate interpretation of this reviewed data, more than twice as many studies among the random sample as compared with Rushton's (46.2 vs 19.4\%) used some method of socioeconomic adjustment (sample restriction, matching or mathematical modeling); $\chi^{2}(1)=7.15, P<0.01$. Relatedly, five of the studies included in Rushton's review (13.9\%) were based upon inter-country comparisons (e.g. U.S. vs Japan or Nigeria) which may tend to overestimate the hypothesized race-behavior effect due to genetic variability by not accounting for between-country environmental 
variability (five inter-country outcomes, $r^{2}=13.0 \%$ vs 35 intra-country ones, $r^{2}=2.5 \%, F(1$, $38)=8.42, P<0.01)$, whereas, only two of the randomly selected studies $(3.1 \%)$ used such comparisons; $\chi^{2}(1)=4.18, P<0.05$.

\section{The association of race with selected behavioral characteristics}

A first scan of the overall summary findings outlined in the top half of Table 1 which concern the quantitative replication of Rushton's review would seem to lend credence to his original conclusion, that significant differences exist between the races across the five observed behavioral domains. Combined probabilities for domains with at least two study outcomes were all found to be significant in a statistical sense and also, it would seem, substantively. For example, average $r$ s ranged from 0.134 (black-white sexuality comparison) to 0.226 (black-white intelligence comparison). Such effect sizes though may be interpreted to roughly mean that only 2-5\% of the observed behavioral variability $\left(r^{2}\right)$ may be accounted for by race, and the dominant cross-sectional design among the original primary studies does not allow for the inference that this is a genetic effect per se-environmental factors remain uncontrolled. This quantitative replication qualifies Rushton's original review findings in a number of other ways: (1) essentially no empirical data existed among Rushton's originally selected studies to support the notion that differences exist between racial groups on social organization (e.g. mental health or law abidingness) - only one non-significant study was represented among the sample; (2) personality and temperament inferences were also based upon what would seem to be very tentative empirical grounds - only two studies, one each black-white and Asian-white comparison, were reviewed, leaving selection bias a very potent alternative explanation; and (3) inferences which concern Asian-white comparisons were also based upon limited data-11 data points or study outcomes provided all of the information for hypothesis testing and theory development across the five observed behavioral domains.

As for the overall random or comparison review, it also found little to no evidence of race-personality/temperament or race-social organization associations (see bottom half of Table 1). Also, similar to Rushton's quantitatively replicated findings, little evidence was suggestive of Asian-white behavioral differences. Only one behavioral domain's combined probability, which itself was based upon a small sample of only three studies, was found to be statistically significant, that is, maturation. The other four domains were summarily not significant for Asian-white comparisons. Even among significant black-white behavioral comparisons, race was estimated to account for very little behavioral variability: sexuality $(0.9 \%)$, maturation (1.6\%) and intelligence $(2.2 \%)$. A final overall caveat would tend to put caution into any theory which is built upon racial group differences: One-third of the outcomes from the randomly selected studies $(27$ of $73,37.0 \%)$ were null or counter to Rushton's hypotheses.

Effect size estimates which are averaged across behavioral domains and racial comparisons and serve to compare Rushton's central quantitatively replicated review finding with these authors' random one are displayed in Table 2 . As for the amount of overall behavioral variability which may be accounted for by race, the effect estimated by Rushton (3.4\%) was found to be more than eight times the estimate based upon a random selection of studies $(0.4 \%)$. Focusing upon this random review's finding, less than one half of one per cent of the behavioral variability was accounted for by race, and again, this is not necessarily a genetic effect; environmental factors, specifically, socioeconomic ones are as of yet unaccounted for in these analyses.

Adjustment for socioeconomic-related environmental factors. This section may serve as an interpretive adjunct for this review's overall findings as well as an examplary analog to the historical misinterpretation of the data in this field when socioeconomic factors are unaccounted for. For example, focusing upon the random sample of 23 studies related to the race-intelligence association, a cornerstone of Rushton's theorizing, the average effect $(r, \mathrm{SD})$ was estimated to be much smaller among the 13 socioeconomic-adjusted outcomes $(0.067,0.138)$ as compared to the 10 unadjusted ones $(0.203,0.129) ; F(1,21)=5.84, P<0.05$. In fact, in terms of intelligence variability which may be accounted for by race $\left(r^{2}\right.$, the unadjusted estimate $(4.1 \%)$ was found to be 10 times the adjusted one $(0.4 \%)$. It ought to be noted here that this very small effect, that is, that race accounts for less than one half of one per cent of intellectual variability, was estimated with very gross environmental adjustment. Only one parameter of the environment was accounted for (i.e. socioeconomic status), 


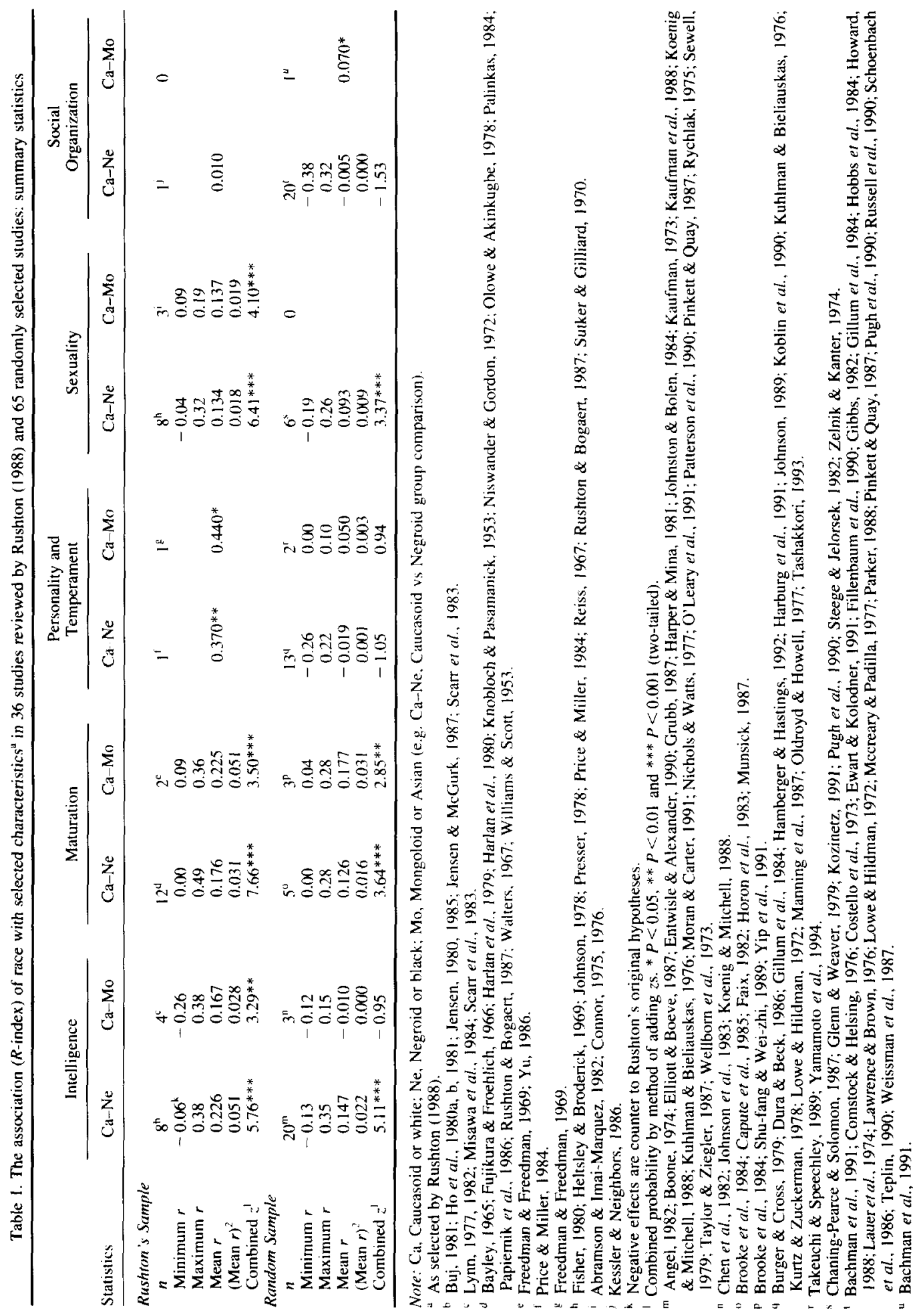




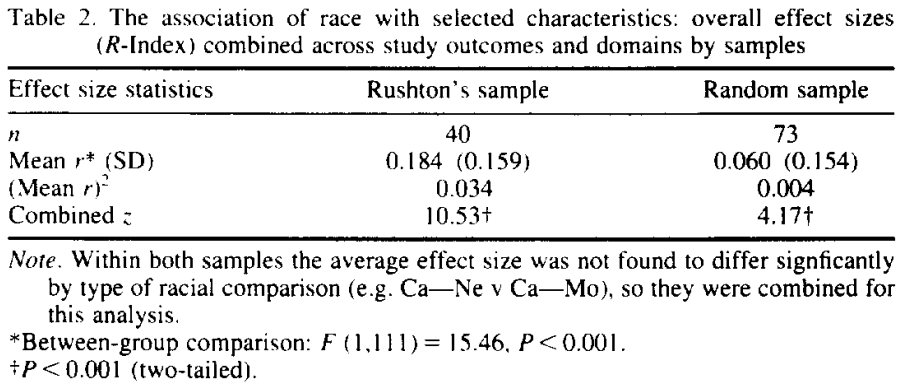

and this factor was typically measured in an imprecise way, for example, a dichotomous measure of annual family income or personal educational achievement was used. So even this review's socioeconomic-adjusted estimate probably represents an overestimate of the truth in nature.

Finally, all of the study outcomes from both Rushton's original and this random review were summarized together. In terms of the behavioral variability which may be accounted for by race, the unadjusted estimate $\left(r^{2}=2.0 \%, n=42\right)$ was again found to be 10 times the one adjusted for socioeconomic factors $(0.2 \%, 71) ; F(1,111)=9.75, P<0.01$, and the combined probability of the average adjusted estimate was found to be not statistically significant $(z=1.59)$.

\section{DISCUSSION}

First, having provided some measure of control for potential selection bias in Rushton's (1988) original review and evolutionary analysis, this review, which was based upon a randomly selected sample of studies, found little evidence of the racial group behavioral differences upon which Rushton had based his theoretical analysis. Averaging across the five behavioral domains described by Rushton (intelligence, maturation, personality and temperament, sexuality, and social organization), an estimate of the amount of behavioral variability which may be accounted for by race among randomly selected studies $(0.4 \%)$ was found to be a small fraction of the one based upon a quantitative replication of Rushton's original selected studies (3.4\%). Next, some measure of review adjustment for a potentially potent alternative explanation, that is, the socioeconomic environment, was provided by comparing those outcomes from studies which used any such control procedure (sample restriction, matching or mathematical modeling) with those that did not. Using all of this review data from studies selected randomly as well as those selected by Rushton, the outcomes of socioeconomic-adjusted studies on average accounted for a very small proportional fraction of race-behavior variability $(0.2 \%)$ as compared with unadjusted studies $(2.0 \%)$. In fact, the combined probability that the summary estimate among studies adjusted for socioeconomic status $(0.2 \%)$ could be explained by sampling error was greater than $5 \%$-not statistically significant.

The results of this meta-analysis, which included a quantitative replication of Rushton's original review, would seem clearly to support the following notions: (1) that selection as well as the third variable' of the socioeconomic environment are potent confounders which were left uncontrolled for in Rushton's original analysis; and (2) after adjustment for them, none of the null hypotheses concerning race differences in behavior can be rejected. Any behavioral differences which do exist between blacks, whites and Asian Americans for example, can be explained in toto by environmental differences which exist between them. Since Rushton's original evolutionary analysis, specifically, the application of $K$-selection theory to human racial groups, was built upon the biased empirical notion that genetic differences exist which account for behavioral differences between the races, we believe it is now unequivocally clear that this theoretical house has not only faltered, but has crumbled to the ground - the foundation upon which it was built is not only unsound, but in a sense, it never existed.

\section{REFERENCES-SPECIAL SECTION A}

Anderson, J. L. (1991). Rushton's racial comparisons: an ecological critique of theory and method. Canadian Psychology, $32,51-60$.

Bogaert, A. F. \& Rushton, J.P. (1989). Sexuality, delinquency and $r / K$ reproduction strategies: data from a Canadian university sample. Personality and Individual Differences, 10, 1071-1077. 
Cain, D. P. \& Vanderwolf, C. H. (1990). A critique of Rushton on race, brain size and intelligence. Personality and Individual Differences, $11,777-784$

Cunningham, M. R. \& Barbee, A. P. (1991). Differential K-selection versus ecological determinants of race differences in sexual behavior. Journal of Research in Personality, 25, 205-217.

Fairchild, H. H. (1991). Scientific racism: the cloak of objectivity. Journal of Social Issues, 47, $101-115$.

Gross, B. R. (1990). The case of Philippe Rushton. Academic Questions, 3, 35-46.

Lynn, R. (1990). New evidence on brain size and intelligence: A comment on Rushton and Cain and Vanderwolf. Personality and Individual Differences, $11,795-797$.

Lynn, R. (1990). Testosterone and gonadotropin levels and $r / K$ reproductive strategies. Psychological Reports, 67, $1203-1206$.

Miller, E. M. (1993) Could $r$ selection account for the African personality and life cycle? Personality and Individual Differences, 15, 665-675.

Roberts, J. V. \& Gabor, T. (1990). Lombrosian wine in a new bottle: Research on crime and race. Canadian Journal of Criminology, 32, 291-313.

Rushton J. P. (1988). The reality of racial differences: a rejoinder with new evidence. Personality and Individual Differences, $9,1035-1040$

Rushton J. P. (1989). The evolution of racial differences: A response to M. Lynn. Journal of Research in Personality. 23. $7-20$.

Rushton J. P. (1989). The generalizability of genetic estimates. Personality and Individual Differences, 10, $985-989$.

Rushton J. P. (1989). Genetic similarity, human altruism, and group selection. Behavioral and Brain Sciences, /2, 503-559.

Rushton J. P. (1989). Japanese inbreeding depression scores: Predictors of cognitive differences between blacks and whites. Intelligence, 13, 43-51.

Rushton J. P. (1989). Race differences in sexuality and their correlates: another look and physiological models. Journal of Research in Personality, 23, 35-54.

Rushton J. P. (1990). Race, brain size and intelligence: A rejoinder to Cain and Vanderwolf. Personality and Individual Differences, $11.785-794$

Rushton J. P. (1990). Race, brain size, and intelligence: A reply to Cernovsky. Psychological Reports, 66, 659-666.

Rushton J. P. (1990). Race and crime: A reply to Roberts and Gabor. Canadian Joumal of Criminology. 32, 315-334

Rushton J. P. (1990). Race differences and $r / K$ theory: A reply to Silverman. Ethology and Sociobiology, $11,131-140$.

Rushton J. P. (1991). Do $r / K$ strategies underlie human race differences? A reply to Weizmann et al. Canadian Psychology, 32. $29-42$.

Rushton J. P. (1991) Mongoloid-Caucasoid differences in brain size from military samples. Intelligence, 15, 351-359.

Rushton J. P. (1991). Race, brain size and intelligence: another reply to Cernovsky. Psychological Reports, 68, $500-502$.

Rushton J. P. (1992). Cranial capacity related to sex, rank, and race in a stratified random sample of 6,325 U.S. military personnel. Intelligence, $16,401-413$.

Rushton J. P. (1992). Contributions to the history of psychology: XC. Evolutionary biology and heritable traits (with reference to oriental-white-black differences): The 1989 AAAS paper. Psychological Reports, 71, 811-821.

Rushton J. P. (1993). Corrections to a paper on race and sex differences in brain size and intelligence. Personality and Individual Differences, 15, 229-231.

Rushton, J. P. \& Ankney, C. D. (1993). The evolutionary selection of human races: A response to Miller. Personality and Individual Differences, 15, 677-680.

Rushton, J. P. \& Bogaert, A. F. (1989). Population differences in susceptibility to AIDS: An evolutionary analysis. Social Science and Medicine, 28, 1211-1220.

Rushton, J. P. \& Bogaert, A. F. (1988). Race versus social class differences in sexual behavior: A follow-up test of the $r / K$ dimension. Journal of Research in Personality, 22, 259-272.

Vanderwolf, C. H. \& Cain, D. P. (1991). The neurobiology of race and Kipling's cat. Personality and Individual Differences, 12, 97-98.

Weizman, F., Wiener, N. I., Wiesenthal, D. L. \& Ziegler. M. (1990). Differential $K$ theory and racial hierarchies. Canadian Psychology, 31, 1-13

Weizman, F.. Wiener, N. I., Wiesenthal, D. L. \& Ziegler, M. (1991). Eggs, eggplants and eggheads: A rejoinder to Rushton. Canadian Psychology, 32, 43-50.

Zuckerman, M. (1990). Some dubious premises in research and theory on racial differences: Scientific, social and ethical issues. American Psychologist, 45, $1297-1303$

Zuckerman, M. \& Brody, N. (1988). Oysters, rabbits and people: A critique of "race differences in behaviour" by J. P. Rushton. Personality and Individual Differences, 9, 1025-1033.

\section{REFERENCES-SPECIAL SECTION B}

Abramson, P. R. \& Imai-Marquez, J. (1982). The Japanese-American: A cross-cultural, cross-sectional study of sex guilt. Journal of Research in Personality, 16, 227-237.

Bayley, N. (1965). Comparisons of mental and motor test scores for ages 1-15 months by sex, birth order, race, geographical location, and education of parents. Child Development, 36, 379-411.

Buj, V. (1981). Average IQ values in various European countries. Personality and Individual Differences, 2. $168-169$

Connor, J. W. (1975). Value changes in third generation Japanese Americans. Journal of Personality Assessment. 39, 597-600.

Connor, J. W. (1976). Family bonds, maternal closeness. and the suppression of sexuality in three generations of Japanese Americans. Ethos, 4 189-221.

Fisher, S. (1980). Personality correlates of sexual behavior in black women. Archives of Sexual Behavior, 9, 27-35.

Freedman, D. G. \& Freedman, N. C. (1969). Behavioral differences between Chinese-American and European-American newborns. Nature, 224, 1227.

Fujikura, T. \& Froehlich, L. A. (1966). The influence of race and other factors on pulmonary hyaline membranes. American Journal of Obstetrics and Gynecology: 95, 572-578.

Harlan. W. R., Grillo, G. P., Comoni-Huntley, J. \& Leaverton, P. E. (1979). Secondary sex characteristics of boys 12 to 17 years of age: the U.S. Health Examination Survey. Journal of Pediatrics, 95, 293-297. 
Harlan, W. R., Harlan, E. A. \& Grillo, G. P. (1980). Secondary sex characteristics of girls 12 to 17 years of age: The U.S. Health Examination Survey. Journal of Pediatrics, 96, 1074-1078.

Heltsley, M. E. \& Broderick, C. B. (1969). Religiosity and premarital sexual permissiveness: Reexamination of Reiss's traditionalism proposition. Journal of Marriage and the Family, 21, 441-443.

Ho, K-C., Roessmann, U., Straumfjord, J. V. \& Monroe, G. (1980a). Analysis of brain weight. I. Adult brain weight in relation to sex, race, and age. Archives of Pathology and Laboratory Medicine, 104, 635-639.

Ho, K-C., Roessmann, U., Straumfjord, J. V. \& Monroe, G. (1980b). Analysis of brain weight II. Adult brain weight in relation to body height, weight and surface area. Archives of Pathology and Laboratory Medicine, 104, 640-645.

Ho, K-C., Roessman, U., Hause, L. \& Monroe, G. (1981). Newborn brain weight in relation to maturity, sex, and race. Annals of Neurology, 10, 243-246.

Jensen, A. R. (1980). Bias in mental testing. New York: Free Press.

Jensen, A. R. (1985). The nature of the black-white difference on various psychometric tests: Spearman's hypothesis. Behavioral and Brain Sciences, 8, 193-263.

Jensen, A. R. \& McGurk, F. C. J. (1987). Black-white bias in 'cultural' and 'noncultural' test items. Personality and Individual Differences, 8, 295-301.

Johnson, L. B. (1978). Sexual behavior of Southern blacks. In Staples, R. (Ed.), The black family: Essays and studies (2nd edn, pp. 80-93). Belmont, CA: Wadsworth.

Kessler, R. C. \& Neighbors, H. W. (1986). A new perspective on the relationships among race, social class, and psychological distress. Journal of Health and Social Behavior, 27, 107-111.

Knobloch, H. \& Pasamanick, B. (1953). Further observations on the behavioral development of Negro children. Journal of Genetic Psychology, 83, 137-157.

Lynn, R. (1977). The intelligence of the Japanese. Bulletin of the British Psychological Society, 30, 69-72.

Lynn, R. (1982). IQ in Japan and the United States shows a growing disparity. Nature, 297, 222-223.

Misawa, G., Motegi, M., Fujita, K. \& Hattori, K. (1984). A comparative study of intellectual abilities of Japanese and American children on the Columbia Mental Maturity Scale (CMMS). Personality and Individual Differences, 5, 173-181.

Niswander, K. R. \& Gordon, M. (1972). The women and their pregnancies. Philadelphia, PA: W. B. Saunders.

Olowe, S. A. \& Akinkugbe, A. (1978). Amniotic fluid lecithin/sphingomyelin ratio: Comparison between an African and a North American community. Pediatrics, 62, 38-41.

Palinkas. L. A. (1984). Racial differences in accidental and violent deaths among U.S. Naval personnel (Report No. 84-45). San Diego, CA: Naval Health Research Center.

Papiernik, E., Cohen, H., Richard, A., de Oca, M. M. \& Feingold, J. (1986). Ethnic differences in duration of pregnancy. Annals of Human Biology. 13, 259-265.

Presser, H. B. (1978). Age at menarche, socio-sexual behavior, and fertility. Social Biology, 25, 94-101.

Price, J. H. \& Miller, P. A. (1984). Sexual fantasies of black and of white college students. Psychological Reports, 54, $1007-1014$.

Reiss, I. L. (1967). The social context of premarital sexual permissiveness. New York: Holt, Rinehart \& Winston.

Rushton, J. P. \& Bogaert, A. F. (1987). Race differences in sexual behavior: Testing an evolutionary hypothesis. Journal of Research in Personality, 21,529-551.

Scarr, S., Caparulo, B. K.. Ferdman, B. M., Tower, R. B. \& Caplan, J. ( 1983). Developmental status and school achievements of minority and non-minority children from birth to 18 years in a British Midlands town. British Journal of Developmental Psychology, 1, 31-48.

Sutker, P. B. \& Gillard, R. S. (1970). Personal sexual attitudes and behavior in blacks and whites. Psychological Reports, $27,753-754$.

Walters, C. E. (1967). Comparative development of Negro and white infants. Journal of Genetic Psychology, 110, 243-251.

Williams, J. R. \& Scott, R. B. (1953). Growth and development of Negro infants: IV. Motor development and its relationship to child rearing practices in two groups of Negro infants. Child Development, 24, 103-121.

Yu, E. S. H. (1986). Health of the Chinese elderly in America. Research on Aging, 8, 84-109.

\section{REFERENCES-SPECIAL SECTION C}

Angel, T. L. (1982). A new measure of growth efficiency: skull base height. American Journal of Physical Anthropology, $58,297-305$

Bachman, J. G., Wallace, J. M., O'Malley, P. M., Johnston, L. D., Kurth, C. L. \& Neighbors, H. W. (1991). Racial/ethnic differences in smoking, drinking, and illicit drug use among American high school seniors, 1976-89. American Journal of Public Health, 81, 372-377.

Boone, J. A. (1974). Racial differences on a black intelligence test. Journal of Negro Education, 43, 429-436.

Brooke, O. G., Wood, C. \& Butters, F. (1984). The body proportions for small-for-date infants. Eearly Human Development, $10,85-94$.

Burger, G. K. \& Cross, D. T. (1979). Personality types as measured by the California Psychological Inventory. Journal of Consulting and Clinical Psychology, 47, 65-71.

Capute, A. J., Shapiro, B. K.. Palmer, F. B., Ross, A. \& Watchel, R. C. (1985). Normal gross motor development: the influences of race, sex and socio-economic status. Developmental Medicine and Child Neurology, 27, 635-643.

Chaning-Pearce, S. M. \& Solomon, L. (1987). Pubertal development in black and white Johannesburg girls. South African Medical Journal, $71,22-24$

Chen, M. J., Braithwaite, V. \& Huang, J. T. (1982). Attributes of intelligent behavior: Perceived relevance and difficulty by Australian and Chinese students. Journal of Cross-Cultural Psychology, 13, 139-156.

Comstock, G. W. \& Helsing, K. J. (1976). Symptoms of depression in two communities. Psychological Medicine, 6, 551-553.

Costello, R. M., Fine, H. J. \& Blau, B. 1. (1973). Racial comparisons on the Minnesota Multiphasic Personality Inventory. Journal of Clinical Psychology, 29,63-65.

Dura, J. R. \& Beck, S. (1986). Psychiatric aide's perceptions of a patient's assertive behaviors. Behavior Modification, 10, 301-303. 
Elliott, S. N. \& Boeve, K. (1987). Stability of WISC-R IQs: An investigation of ethnic differences over time. Educational and Psychological Measurement, 47, 461-465.

Entwisle, D. R. \& Alexander, K. L. (1990). Beginning school math competence: Minority and majority comparisons. Child Development, 61, 454-471.

Ewart, C. K. \& Kolodner, K. B. (1991). Social competence interview for assessing psychological reactivity in adolescents. Psychosomatic Medicine, 53, 289-304.

Faix, R. G. (1982). Fontanelle size in black and white term newborn infants. Journal of Pediatrics, 100, 304-306.

Fillenbaum, G., Heyman, A., Williams, K., Presnitz, B. \& Burchett, B. (1990). Sensitivity and specificity of standardized screens of cognitive impairment and dementia among elderly black and white community residents. Journal of Clinical Epidemiology, 43, 651-660.

Gibbs, J. J. (1982). Personality pattern of delinquent females: ethnic and sociocultural variations. Journal of Clinical Psychology, 38, 198-206.

Gillum, R. F., Gomez-Marin, O. \& Prineas, R. J. (1984). Racial differences in personality, behavior, and family environment in Minneapolis school children. Journal of the National Medical Association, 76, 1097-1105.

Glenn, N. D. \& Weaver, C. N. (1979). Attitudes toward premarital, extramarital and homosexual relations in the U.S. in the 1970s. Journal of Sex Research, 15, 108-118.

Grubb, H. J. (1987). Intelligence at the low end of the curve: Where are the racial differences? Journal of Black Psychology, $14,25-34$

Hamberger, L. K. \& Hastings, J. E. (1992). Racial differences on the MCMI in an outpatient clinical sample. Journal of Personality Assessment, 58, 90-95.

Harburg, E., Gleiberman, L., Russell, M. \& Cooper, M. L. (1991). Anger coping styles and blood pressure in black and white males: Buffalo, New York. Psychosomatic Medicine, 53, 153-164.

Harper, C. \& Mina, L. (1981). A comparison of Australian Caucasian and Aboriginal brain weights. Clinical and Experimental Neurology, I8, 44-51.

Hobbs, S. A., Walle, D. L. \& Hamersly, G. A. (1984). Assessing children's social skills: Validation of the Behavioral Assertiveness Test for Children (BAT-C). Journal of Behavioral Assessment, 6, 29-35.

Horon, I. L., Strobino, D. M. \& MacDonald, H. M. (1983). Birth weights among infants born to adolescent and young adult women. American Joumal of Obstetrics and Gynecology, 146, 444-449.

Howard, J. A. (1988). A structural approach to sexual attitudes: Interracial patterns in adolescens' judgments about sexual intimacy. Sociological Perspectives, 31, 88-121

Johnson, E. H. (1989). The role of the experience and expression of anger and anxiety in elevated blood pressure among black and white adolescents. Journal of the National Medical Association, 81, 573-584.

Johnson, R. C., Nagoshi, C. T., Ahern, F. M., Wilson, J. R., DeFries, J. C., McClearn, G. E. \& Vandenberg, S. G. (1983). Family background, cognitive ability, and personality as predictors of educational and occupational attainment. Social Biology, 30,86-100.

Johnston, W. T. \& Bolen, L. M. (1984). A comparison of the factor structures of the WISC-R for blacks and whites. Psychology in the Schools, 21, 42-48.

Kaufman, A. S. (1973). Comparison of the performance of matched groups of black children and white children on the Wechsler Preschool and Primary Scale of intelligence. Journal of Consulting and Clinical Psychology, 4I, 186-191.

Kaufman, A. S., McLean, J. E. \& Reynolds, C. R. (1988). Sex, race, residence, region, and education differences on the 11 WAIS-R subtests. Journal of Clinical Psychology, 44, 231-248.

Koblin, B. A., McCusker, J., Lewis, B. F. \& Sullivan, J. L. (1990). Racial/ethnic differences in HIV-1 seroprevalence and risky behaviors among intravenous drug users in a multisite study. American Journal of Epidemiology, 132, 837-846.

Koenig, J. A. \& Mitchell, K. J. (1988). An interim report on the MCAT essay pilot project Journal of Medical Education, $63,21-29$.

Kozinetz, C. A. (1991). Sexual maturation and blood pressure levels of a biracial sample of girls. American Journal of Diseases of Children, 145, 142-146.

Kuhlman, T. L. \& Bieliauskas, V. J. (1976). A comparison of black and white adolescents on the HTP. Journal of Clinical Psychology, 32, 728-731.

Kurtz, J. P. \& Zuckerman, M. (1978). Race and sex differences on the sensation seeking scales. Psychological Reports, 43, $529-530$

Lauer, B., Tenbroeck, E. \& Grossman, M. (1974). Battered child syndrome: Review of 130 patients with controls. Pediatrics, $54,67-70$.

Lawrence, W. \& Brown, D. (1976). An investigation of intelligence, self-concept, socioeconomic status, race, and sex as predictors of career maturity. Journal of Vocational Behavior, 9, 43-52.

Lowe, J. D. Jr \& Hildman, L. K. (1972). EPI scores as a function of race. British Journal of Social and Clinical Psychology, Il, 191-192.

Manning, D. T., Balson, P. M., Hunter, S. M., Berenson, G. S \& Willis, A. S. (1987). Comparison of the prevalence of Type A behavior in boys and girls from two contrasting socioeconomic status groups. Journal of Human Stress, 13, 116-120.

Mccreary, C. \& Padilla, E. (1977). MMPI differences among black, Mexican-American, and white male offenders. Journal of Clinical Psychology, 33, 171-177.

Moran, J. J. \& Carter, D. E. (1991). Comparison among children's responses to the Hand test by grade, race, sex, and social class. Journal of Clinical Psychology, 47, 647-664.

Munsick, R. A. (1987). Siimilarities of Negro and Caucasian fetal extremity lengths in the interval from 9 to 20 weeks of pregnancy. American Journal of Obstetrics and Gynecology, 156, 183-185.

Nichols, N. J. \& Watts, A. (1977). Black or white socio-economically disadvantaged pupils-they aren't necessarily inferior. Journal of Negro Education, 46, 443-449.

Oldroyd, R. J. \& Howell, R. J. (1977). Personality, intellectual, and behavioral differences between black, Chicano and white prison inmates in the Utah State Prison. Psychological Reports, 41, 187-191.

O'Leary, U-M., Rusch, K. M. \& Guastello, S. J. (1991). Estimating age-stratified WAIS-R IQs from scores on the Raven's standard progressive matrices. Journal of Clinical Psychology, 47, 277-284.

Parker, K. D. (1988). Black-white differences in perceptions of fear of crime. Journal of Social Psychology, $128,487-494$.

Patterson, C. J., Kupersmidt, J. B. \& Vaden, N. A. (1990). Income level, gender, ethnicity, and household composition as predictors of children's school-based competence. Child Development, 61, 485-494. 
Pinkett, K. E. L. \& Quay, L. C. (1987). Race versus social class: social orientation and cognitive play in black and white middle SES preschool children. Journal of Applied Developmental Psychology, 8, 343-350.

Pugh, M. D., DeMaris, A., Giordano, P. C. \& Groat, H. T. (1990). Delinquency as a risk factor in teenage pregnancy. Sociological Focus, 23, 89-100.

Russell, M., Cooper, M. L. \& Frone, M. R. (1990). The influence of socio demographic characteristics on family alcohol problems: Data from a community sample. Alcoholism: Clinical and Experimental Research, 14, $221-226$.

Rychlak, J. F. (1975). Affective assessment, intelligence, social class, and racial learning style. Journal of Personality and Social Psychology, 32, 989-995

Schoenbach, V. J., Kaplan, B. H., Fredman, L. \& Kleinbaum, D. G. (1986). Social ties and mortality in Evans County, Georgia. American Journal of Epidemiology: 123, 577-591.

Sewell, T. E. (1979). Intelligence and learning tasks as predictors of scholastic achievement in black and white first-grade children. Journal of School Psychology, 17, 325-332.

Shu-fang, L., \& Wei-zhi, D. (1989). A growth velocity standard for Chinese children in Hong Kong, Chinese Medical Journal $102,233-235$

Steege, J. F. \& Jelorsek, F. R. (1982). Sexual behavior during pregnancy. Obstetrics and Gynecology, 60, $163-168$.

Takeuchi, D. T. \& Speechley, K. N. (1989). Ethnic differences in the marital status and psychological distress relationship. Social Psychiatry and Psychiatric Epidemiology, 24, 288-294.

Tashakkori, A. (1993). Race, gender and pre-adolescent self-structure: A test of construct-specificity hypothesis. Personality and Individual Differences, 14, 591-598.

Taylor, R. L. \& Ziegler, E. W. (1987). Comparison of the tirst principal factor on the WISC-R across ethnic groups Educational and Psichological Measurement, 47, 691-694.

Teplin, L. A. (1990). The prevalence of severe mental disorder among male urban jail detainees: Comparison with the epidemiologic catchment area program. American Journal of Public Health. 80, 663-669.

Weissman, M. M., Leaf, P. J.\& Bruce, M. L. (1987). Single parent women: a community study. Social Psychiatry, 22, 29-36.

Wellborn, E. S., Reid, W. R. \& Reichard, C. L. (1973). Effect of examiner race on test scores of black and white children. Education and Training of the Mentally Retarded. 8, 194-199.

Yamamoto, J., Rhee, S. \& Chang, D-S. ( 1994 ). Psychiatric disorders among elderly Koreans in the United States. Community Mental Health Journal, $30,17-27$.

Yip, R., Li, Z. \& Chong, W-H. (1991). Race and birth weight: The Chinese example. Pediatrics, 87, $688-693$.

Zelnik, M. \& Kanter, J. F. (1974). The resolution of teenage first pregnancies. Family Planning Perspectives, 6, 74-80.

\section{REFERENCES}

Cooper, H. M. (1989). Integrating research: A guide for literature reviens (2nd ed.). Newbury Park, CA: Sage.

Glass, G. V. McGaw, B. \& Smith, M. L. (1981). Meta-analssis in social research. Beverly Hills, CA: Sage.

Lynn, M. (1989a). Criticisms of an evolutionary hypothesis about race differences: A rebuttal to Rushton's reply. Journal of Research in Personality, 23, 21-34.

Lynn, M. (1989b). Race differences in sexual behavior: A critique of Rushton and Bogaert's evolutionary hypothesis. Journal of Research in Personality, 23, 1-6.

Rosenthal, R. (1978). Combining results of independent studies. Psychological Bulletin, 85, 185-193.

Rothman, K. J. (1986). Modern epidemiology: Boston, MA: Little. Brown and Company.

Rushton, J. P. (1988). Race differences in behaviour: a review and evolutionary analysis. Personality and Individual Differences, 9, 1009-1024.

Stouffer, S. A., Suchman, E. A. \& DeVinney, L. L. (1949). The American soldier: Adjustment during army life (Vol. 9) Princeton, NJ: Princeton University Press. 